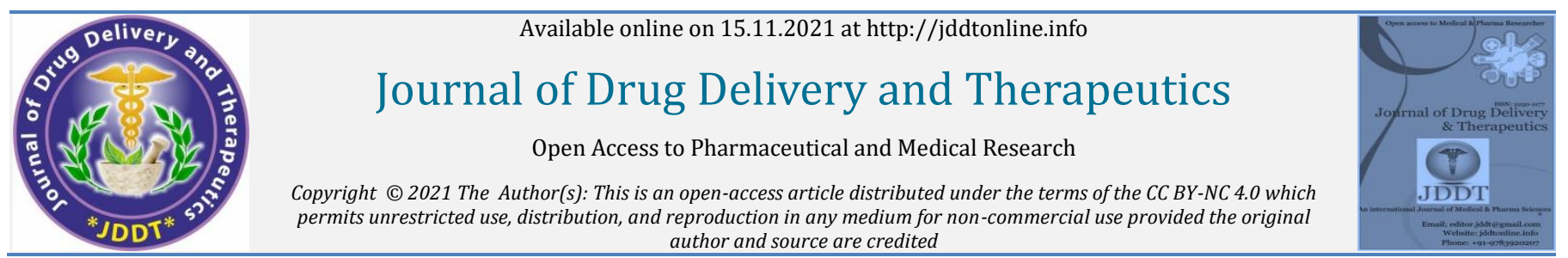
author and source are credited

Open Access Full Text Article (C)

Research Article

\title{
Retrospective Audit on Cloxacillin Prescription in Primary Health Care Facilities in Kuala Selangor, Malaysia
}

\author{
${ }^{*}$ Farhani Samat ${ }^{1}$ (D) Nurul Nadia Baharum² (D) Nor Anizah Muzaid ${ }^{3}$ (D), Sharifah Nurul Aida Syed Ghazali4 (D), \\ Sharmilee Ramanathan ${ }^{5}$ (D), Nuraini Dolbasir6 (D), Noor Rafizah Aminah Binti Aziz ${ }^{7}$ (D) \\ ${ }^{1}$ Klinik Kesihatan Tanjong Karang, Jalan, Sungai Kajang, 45500 Kuala Selangor, Ministry of Health, Malaysia \\ ${ }^{2}$ Klinik Kesihatan Bukit Cherakah, Jln Rizab Masjid, Kampung Bukit Cherakah, 45800 Jeram, Selangor \\ ${ }^{3}$ Klinik Kesihatan Kuala Selangor, Jalan Klinik, Bandar Malawati, 45000 Kuala Selangor, Selangor \\ ${ }^{4}$ Klinik Kesihatan Bestari Jaya, 1867, Jln Kampung, Pekan Batang Berjuntai, 45600 Batang Berjuntai, Selangor \\ ${ }^{5}$ Klinik Kesihatan Ijok, JKR 1087, Jln 14, Ijok, 45700 Batang Berjuntai, Selangor \\ ${ }^{6}$ Klinik Kesihatan Jeram, Jalan Klang 45800 Jeram Kuala Selangor \\ ${ }^{7}$ Pejabat Kesihatan Daerah Kuala Selangor, Kuala Selangor Health district, Jalan Semarak, Bandar Melawati, 45000 Kuala Selangor, Selangor
}

Article Info:

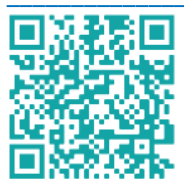

\section{Article History:}

Received 18 September 2021 Reviewed 27 October 2021 Accepted 03 November 2021

Published 15 November 2021

\section{Cite this article as:}

Samat F, Baharum NN, Muzaid NA, Syed Ghazali SNA Ramanathan S, Dolbasir N, Aziz NRAB, Retrospective Audit on Cloxacillin Prescription in Primary Health Care Facilities in Kuala Selangor, Malaysia , Journal of Drug Delivery and Therapeutics. 2021; 11(6):115-120

DOI: http://dx.doi.org/10.22270/jddt.v11i6.5110

\section{*Address for Correspondence:}

Dr Farhani Samat, Family Medicine Specialist, Klinik Kesihatan Tanjong Karang, Jalan, Sungai Kajang, 45500 Kuala Selangor, Ministry of Health, Malaysia

ORCID ID: https://orcid.org/0000-0003-0107-8179

\section{Abstract}

Introduction: Cloxacillin is the second most prescribed antibiotic for skin and soft tissue infection in Malaysia. A similar pattern was seen in Kuala Selangor, in which our district demonstrated that the Defined Daily Dose (DDD) of Cloxacillin is high (3.0-8.7) compared to the recommended value from World Health Organization (WHO). However, resistant patterns for Cloxacillin are alarming. This study focuses on appropriate use of Cloxacillin to prevent further antimicrobial resistance. Methodology: This is a retrospective cross-sectional audit, conducted in seven public health clinics in Kuala Selangor district from January 2020 to March 2020. All Cloxacillin prescriptions within this duration were selected. Audit format was adapted from the antimicrobial stewardship protocol (AMS). Appropriate Cloxacillin use is based on accuracy of diagnosis, indication of antibiotic, correct usage (pharmacological name, dose, frequency and duration). Results: A total of 259 prescriptions were collected. Majority were for age 40 years old, 48.6\% ( $\mathrm{n}=126)$ and male, $63.7 \%(\mathrm{n}=165)$. Cloxacillin was prescribed most for infection of the skin and subcutaneous tissue $64.1 \%(n=166)$. Diagnosis was accurate in $63.7 \%(n=165)$. Those accurate diagnosis, had correct indication 79.4\% (131/165); correct usage 51.5\% (85/165); correct name 69.7\% (115/165); correct frequency 55.2\% (91/165); correct dose $55.8 \%$ (92/165), and correct duration 47.3\% (78/165). Appropriate Cloxacillin use was $41.8 \%$ (69/165). Conclusion: Measures to improve appropriate Cloxacillin use and adherence to the National Antibiotic Guideline (NAG) and Antimicrobial Stewardship (AMS) protocol is crucial.

Keywords: Cloxacillin, Skin and soft tissue infection, Malaysia, antimicrobial resistance

\section{INTRODUCTION}

Appropriateness of antibiotic usage must be monitored to prevent rapid development of antimicrobial resistance. Inappropriate use of antibiotics is a major concern, related to raising health care cost, mortality and ineffective treatment. Antibiotic appropriateness by definition means that the decision about not giving antibiotics is correct as far as the bacteria is susceptible to the prescribed antibiotic or the culture is negative. Meanwhile, inappropriate use of antibiotics means under-treatment (patient not receiving antibiotic that is susceptible to the bacteria) or overtreatment (patient unnecessarily treated with antibiotics) ${ }^{1}$.
National Antibiotic Guidelines (NAG) was launched in 2008 by the Malaysia Government as a method of monitoring the appropriate use of antibiotics in all healthcare facilities in Malaysia under the Ministry of Health. Latest version of NAG 2019 has been officially launched by $\mathrm{MOH}^{2}$ and recommendations for utilization of Cloxacillin as antibiotic of choice has been outlined clearly in the new guidelines. Based on the recommendation, Cloxacillin used is mainly reserved for treatment of susceptible bacterial infections, notably penicillinase-producing staphylococci infections ${ }^{3}$, especially Streptococcus pyogenes and Staphylococcus aureus infection.

In Malaysia, national surveillance on antibiotic utilization primarily looks at hospitals and intensive care units setting antibiotic prescription, rather than outpatient public health 
Samat et al

clinics. Based on the Malaysia Health Systems Research (MHSR) 2016, Malaysia is facing acute rising in health expenditures ${ }^{4}$ in which further steps need to be commenced including looking into appropriate utilization of antibiotics in outpatient public health clinics.

Cloxacillin is the second most prescribed antibiotic for skin and soft tissue infection in Malaysia ${ }^{5}, 6$. A study on the outpatient public health clinic prescriptions ${ }^{6}$ showed that antibiotic prescription for skin and soft tissue infections is the second most common after upper respiratory tract infections (URTIs), whereby Cloxacillin and amoxicillin/clavulanic acid are the second and third most frequently prescribed antibiotic ${ }^{7}$. Further study by Shamsuddin, Akkawi, Zaidi, Ming and Manan ${ }^{5}$ showed that Cloxacillin is the second most common antibiotic used in three major primary health clinics in Selangor, with 0.68 Defined Daily Dose (DDD) per 1000 inhabitants-day, with also the second-most common antibiotic prescriptions for all categories of age group, ranging from 18 to 60 years old.

A similar pattern was seen in Kuala Selangor, in which our district demonstrated that the Defined Daily Dose (DDD) of Cloxacillin is high (3.0-8.7) compared to the recommended value from World Health Organization (WHO). Despite Cloxacillin is the second most prescribed antibiotic for skin and soft tissue infection ${ }^{5}, 7$, limited studies have been conducted in looking into appropriate use of Cloxacillin in outpatient settings. Therefore, this audit aims to assess appropriate Cloxacillin use against the National Antibiotic Guideline $^{2}$ among prescribers in public health clinics in Kuala Selangor, Selangor. Other objectives are mainly to describe sociodemographic characteristics of patients prescribed with Cloxacillin, to investigate type of diagnosis stated in Cloxacillin prescriptions and to determine accuracy of diagnosis of Cloxacillin prescriptions.

\section{MATERIALS AND METHODS}

This is a cross-sectional study conducted in seven public health care clinics in Kuala Selangor under Kuala Selangor district health office. All prescriptions that contained Cloxacillin in the outpatient clinics were audited retrospectively. The study was conducted from January 2020 - March 2020.

A total of 259 prescriptions which contained Cloxacillin in the outpatient department from January 2020 until March 2020 were audited. Samples were drawn from PHIS system and
Journal of Drug Delivery \& Therapeutics. 2021; 11(6):115-120 manual records (Jan-March 2020). Only clinical and relevant data from the subjects' record were collected.

Audit format was adapted from the antimicrobial stewardship protocol (AMS) ${ }^{8}$. All prescriptions were audited for all 16 criteria with binary outcome, 'Yes' or 'No' and converted to percentages. However, for criteria 10, 11, 12 and 13, the percentage was calculated by replacing the denominator with those who answered 'Yes' which was "correct antibiotic" for Criteria 9. The percentage for Criteria 4, 15 and 16 were calculated by omitting those not applicable from the denominator. Appropriate Cloxacillin usage is based on accuracy of diagnosis, indication of antibiotic, correct usage (pharmacological name, dose, frequency and duration) against NAG 2019. Data was analyzed using SPSS software. Ethical approval was obtained from Malaysia Medical Research and Ethics Committee (MMREC) prior to the study.

\section{RESULTS}

\section{Sociodemographic characteristics of patients}

A majority of patients receiving antibiotics in this district were $>40$ years old $48.6 \%, n=126$ and predominantly male $63.7 \%, \mathrm{n}=165$ (Table 1).

Table 1: Sociodemographic characteristics of patients receiving Cloxacillin in Kuala Selangor district

\begin{tabular}{|l|l|l|}
\hline & $\begin{array}{l}\text { Distribution of } \\
\text { age }\end{array}$ & $\begin{array}{l}\text { Overall district } \mathbf{N}=259 \text { } \\
\text { (\%) }\end{array}$ \\
\hline Age & $<18$ & $51(19.7)$ \\
\hline & $18-40$ & $82(31.7)$ \\
\hline & $>40$ & $126(48.6)$ \\
\hline Gender & Male & $165(63.7)$ \\
\hline & Female & $94(36.3)$ \\
\hline
\end{tabular}

\section{Distribution of antibiotic prescription}

Most prescriptions were recorded from Kuala Selangor health clinic $21.2 \%(n=55)$ followed by Bestari Jaya health clinic $20.1 \%$ $(n=52)$, Jeram health clinic 18.1\% $(n=47)$. Bukit Cherakah health clinic $16.6 \%(n=43)$. Ijok health clinic 10.0\% $(n=26)$ Tanjong Karang health clinic 9.3\% $(n=24)$ and Sungai Tengi Kanan health clinic $4.6 \%$ (n=12) (Fig 1)

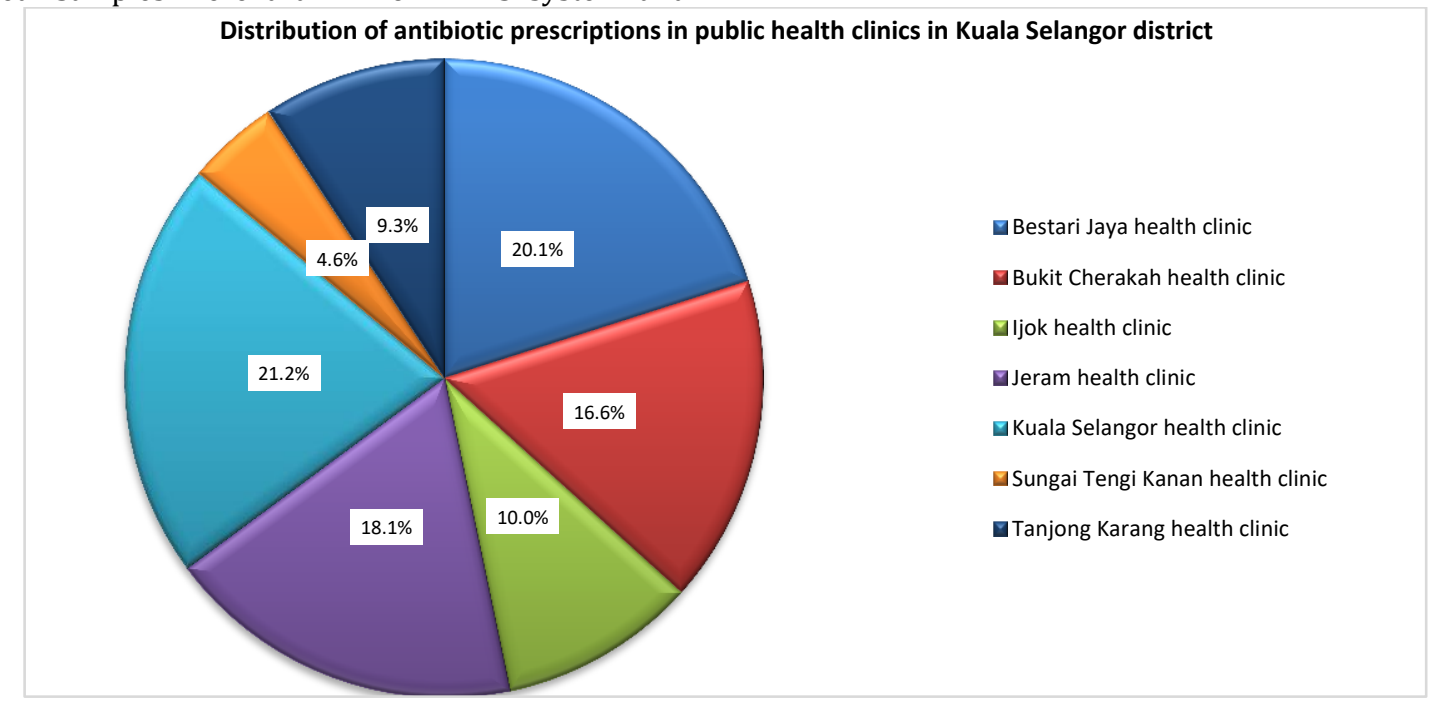

Figure 1: Distribution of antibiotic prescriptions by Klinik Kesihatan in Kuala Selangor 
Samat et al

\section{Adherence of Cloxacillin prescription}

The measure of adherence utilises the fulfillment of the 16 criteria set by the National antibiotic guideline for the antimicrobial stewardship audit that is performed nationwide. 9 out of the 16 criteria achieved the standard of $>80 \%$ which were reason for coming $90.7 \%$ (n-235), physical examination 83.8\% $(n=217)$ and diagnosis documented 81.5\% $(n=211)$. (Table 2)

Only $63.7 \%$ prescriptions $(n=165)$ were deemed accurate diagnosis by the auditors and only $50.6 \% \quad(n=131)$ were
Journal of Drug Delivery \& Therapeutics. 2021; 11(6):115-120 indicated for antibiotics. 68.3\% $(n=177)$ had vital signs documented and $43.5 \%(n=50)$ had relevant investigation. Standards that were poorly scored includes statement of drug allergy $10.8 \%(\mathrm{n}=28)$, health education $6.6 \%(\mathrm{~N}=17)$.

The audit revealed only $36.7 \%$ (n- 95) prescriptions were correct antibiotic based on the National Antibiotic guideline. Out of this total, they attained the percentage for correct pharmacological name was $100 \%$, correct frequency was $97.9 \%$ $(n=93)$, correct dosing was 95.8\% (n=91) while correct duration was the lowest at $85.3 \%(n=81)$.

Table 2: Overall distribution of National antimicrobial stewardship criteria fulfilled by each health clinic.

\begin{tabular}{|c|c|c|c|c|c|c|c|c|}
\hline Adherence to antibiotic criteria & $\begin{array}{l}\text { KKBJ } \\
\text { n (\%) }\end{array}$ & $\begin{array}{l}\text { KKBC } \\
\text { n (\%) }\end{array}$ & $\begin{array}{c}\text { KKI } \\
\text { n (\%) }\end{array}$ & $\begin{array}{c}\text { KKJ } \\
\text { n (\%) }\end{array}$ & $\begin{array}{l}\text { KKKS } \\
\text { n (\%) }\end{array}$ & $\begin{array}{l}\text { KKSTK } \\
\text { n (\%) }\end{array}$ & $\begin{array}{l}\text { KKTK } \\
\text { n (\%) }\end{array}$ & $\begin{array}{l}\text { Overall district } \\
\text { n (\%) }\end{array}$ \\
\hline Reason for coming & $\begin{array}{c}51 \\
(98.1)\end{array}$ & $\begin{array}{c}42 \\
(97.7)\end{array}$ & $\begin{array}{c}21 \\
(80.8)\end{array}$ & $\begin{array}{c}41 \\
(87.2)\end{array}$ & $\begin{array}{c}47 \\
(85.5)\end{array}$ & $\begin{array}{c}12 \\
(100)\end{array}$ & $\begin{array}{c}21 \\
(87.5)\end{array}$ & $\begin{array}{l}235(90.7 \%) \\
N=259\end{array}$ \\
\hline Vital signs & $\begin{array}{c}44 \\
(84.6)\end{array}$ & $\begin{array}{c}39 \\
(90.7)\end{array}$ & $\begin{array}{c}18 \\
(69.2)\end{array}$ & $\begin{array}{c}34 \\
(72.3)\end{array}$ & $\begin{array}{c}9 \\
(16.4)\end{array}$ & $\begin{array}{c}12 \\
(100)\end{array}$ & $\begin{array}{c}21 \\
(87.5)\end{array}$ & $\begin{array}{c}177(68.3) \\
N=259\end{array}$ \\
\hline Physical examination & $\begin{array}{c}43 \\
(82.7)\end{array}$ & $\begin{array}{c}39 \\
(90.7)\end{array}$ & $\begin{array}{c}19 \\
(73.1)\end{array}$ & $\begin{array}{c}44 \\
(93.6)\end{array}$ & $\begin{array}{c}42 \\
(76.4)\end{array}$ & $\begin{array}{c}11 \\
(91.7)\end{array}$ & $\begin{array}{c}19 \\
(79.2)\end{array}$ & $\begin{array}{l}217(83.8) \\
\mathrm{N}=259\end{array}$ \\
\hline Relevant investigation & $5(83.3)$ & $11(84.6)$ & $4(57.1)$ & $13(29.5)$ & $4(20.0)$ & $5(50.0)$ & $8(53.3)$ & $50(43.5) \mathrm{N}=115$ \\
\hline Diagnosis documentation & $40(76.9)$ & $39(90.7)$ & $21(80.8)$ & $34(72.3)$ & $48(87.3)$ & $10(83.3)$ & $19(79.2)$ & $\begin{array}{l}211(81.5) \\
N=259\end{array}$ \\
\hline Accurate diagnosis & $34(35.4)$ & $33(76.7)$ & $19(73.1)$ & $31(66.0)$ & $32(58.2)$ & $4(33.3)$ & $12(50.0)$ & $\begin{array}{c}165(63.7) \\
\mathrm{N}=259\end{array}$ \\
\hline Antibiotic is indicated & $25(48.1)$ & $24(55.8)$ & $16(61.5)$ & $22(46.8)$ & $28(50.9)$ & $4(33.3)$ & $12(50.0)$ & $\begin{array}{c}131(50.6) \\
N=259\end{array}$ \\
\hline Statement of drug allergy & $8(15.4)$ & $6(14.0)$ & $0(0.0)$ & $2(4.3)$ & $8(14.5)$ & $3(25.0)$ & 194.2) & $28(10.8) \mathrm{N}=259$ \\
\hline Correct antibiotic & $\begin{array}{c}16 \\
(47.1)\end{array}$ & $\begin{array}{c}18 \\
(54.5)\end{array}$ & $8(42.1)$ & $23(74.2)$ & $11(34.4)$ & $3(75.0)$ & $6(50.0)$ & $85(51.5) \mathrm{N}=165$ \\
\hline Correct pharmacological name & $\begin{array}{c}16 \\
(47.1)\end{array}$ & $\begin{array}{c}18 \\
(54.5)\end{array}$ & $10(52.6)$ & $29(93.5)$ & $32(100)$ & $4(100)$ & $6(50.0)$ & $\begin{array}{l}115(69.7) \\
N=165\end{array}$ \\
\hline Correct dosing & $\begin{array}{c}16 \\
(47.1)\end{array}$ & $\begin{array}{c}18 \\
(54.5)\end{array}$ & $10(52.6)$ & $29(93.5)$ & $10(31.3)$ & $3(75.0)$ & $6(50.0)$ & $92(55.8) \mathrm{N}=165$ \\
\hline Correct frequency & $\begin{array}{c}16 \\
(47.1)\end{array}$ & $\begin{array}{c}18 \\
(54.5)\end{array}$ & $10(52.6)$ & $28(90.3)$ & $10(31.3)$ & $3(75.0)$ & $6(50.0)$ & $91(55.2) \mathrm{N}=165$ \\
\hline Correct duration & $13(38.2)$ & $16(48.5)$ & $10(52.6)$ & 18(58.1) & $11(34.4)$ & $4(100)$ & $6(50.0)$ & $78(47.3) \mathrm{N}=165$ \\
\hline Health education & $6(11.5)$ & $3(7.0)$ & $0(0.0)$ & $1(2.1)$ & $2(3.6)$ & $3(25.0)$ & $2(8.3)$ & $\begin{array}{c}17(6.6) \\
N=259\end{array}$ \\
\hline $\begin{array}{lll}\begin{array}{l}\text { Appropriate } \\
\text { indicated) }\end{array} & \text { referral } & \text { (if } \\
& & \end{array}$ & $1(33.3)$ & $1(25.0)$ & $1(100)$ & $2(100)$ & $5(19.2)$ & $0(0)$ & $0(0)$ & $\begin{array}{c}10(26.3) \\
N=38\end{array}$ \\
\hline $\begin{array}{llll}\begin{array}{l}\text { Appropriate } \\
\text { indicated) }\end{array} & \text { follow } & \text { up } & \text { (if } \\
\end{array}$ & $19(44.2)$ & $29(80.6)$ & $9(37.5)$ & $29(41.9)$ & $12(22.6)$ & $3(27.3)$ & $7(35.0)$ & $97(42.2) \mathrm{N}=230$ \\
\hline
\end{tabular}

Abbreviations: KKBJ; Bestari Jaya health clinic, KKBC; Bukit Cherakah health clinic, KKI; Ijok health clinic, KKJ; Jeram health clinic, KKKS; Kuala Selangor health clinic, KKSTK; Sungai Tengi Kanan health clinic, KKTK; Tanjong Karang health clinic 


\section{Appropriateness of Cloxacillin use prescribed}

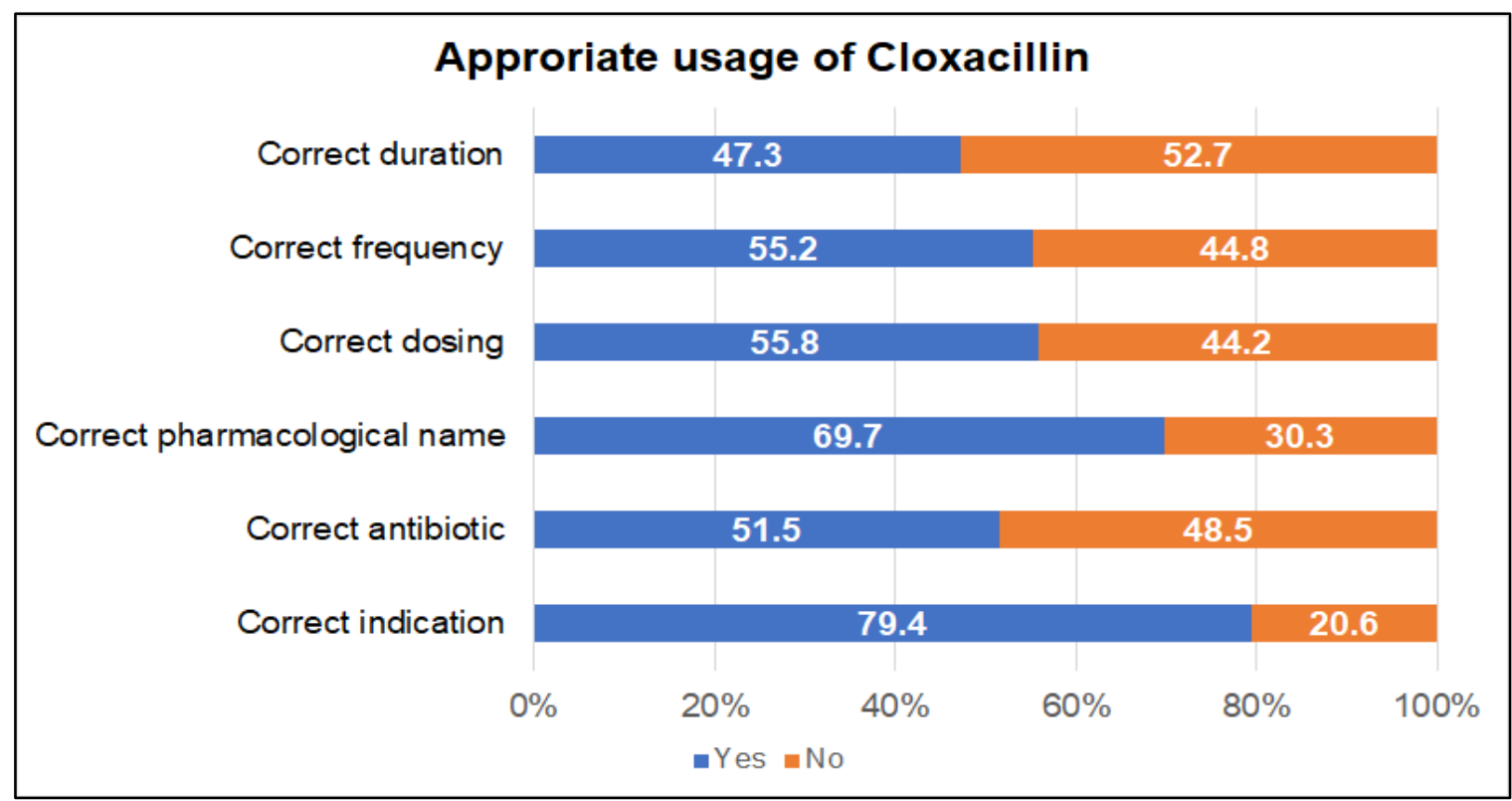

The measure of appropriateness of Cloxacillin is reflected by those fulfilling accurate diagnosis from which they have correct clinical indication for Cloxacillin, correct name, dosing, frequency and duration
Those cases that fulfill all the parameters above are deemed appropriate usage of Cloxacillin, with the overall performance of district Kuala Selangor.

\begin{tabular}{|l|c|c|}
\hline & Total Accurate Diagnosis & $\begin{array}{c}\text { Total Appropriate usage } \\
\text { n (\%) }\end{array}$ \\
\hline KKBJ & $\mathrm{N}=34$ & $13(38.2)$ \\
\hline KKBC & $\mathrm{N}=33$ & $15(45.5)$ \\
\hline KKI & $\mathrm{N}=19$ & $15(42.1)$ \\
\hline KKJ & $\mathrm{N}=31$ & $10(31.3)$ \\
\hline KKKS & $\mathrm{N}=32$ & $2(50.0)$ \\
\hline KKSTK & $\mathrm{N}=4$ & $6(50.0)$ \\
\hline KKTK & $\mathrm{N}=12$ & $69(41.8)$ \\
\hline Overall district & $\mathrm{N}=165$ & \\
\hline
\end{tabular}

Abbreviations: KKBJ; Bestari Jaya health clinic, KKBC; Bukit Cherakah health clinic, KKI; Ijok health clinic, KKJ; Jeram health clinic, KKKS; Kuala Selangor health clinic, KKSTK; Sungai Tengi Kanan health clinic, KKTK; Tanjong Karang health clinic 
Samat et al

\section{Disease distribution given Cloxacillin}

Table 3 demonstrated majority of Cloxacillin was prescribed to infection of the skin and subcutaneous tissue, 64.1\% $(n=166)$
Journal of Drug Delivery \& Therapeutics. 2021; 11(6):115-120 while other diagnosis was almost equal in distribution. However, $18.5 \%(n=48)$ prescriptions that were given had no diagnosis.

Table 3: Disease distribution based on ICD-10 classification that received cloxacillin

\begin{tabular}{|c|c|c|c|c|c|c|c|c|}
\hline $\begin{array}{l}\begin{array}{l}\text { Distribution of } \\
\text { classification }\end{array}\end{array}$ & $\begin{array}{l}\text { KKBJ } \\
\mathrm{N}=52 \\
\text { n (\%) }\end{array}$ & $\begin{array}{l}\text { KKBC } \\
\mathrm{N}=43 \\
\text { n (\%) }\end{array}$ & $\begin{array}{c}\text { KKI } \\
\mathrm{N}=26 \\
\mathrm{n}(\%)\end{array}$ & $\begin{array}{c}\text { KKJ } \\
\mathrm{N}=47 \\
\text { n (\%) }\end{array}$ & $\begin{array}{l}\text { KKKS } \\
\text { N=55 } \\
\text { n (\%) }\end{array}$ & $\begin{array}{c}\text { KKSTK } \\
\text { N=12 } \\
\text { n (\%) }\end{array}$ & $\begin{array}{l}\text { KKTK } \\
\mathrm{N}=24 \\
\text { n (\%) }\end{array}$ & $\begin{array}{c}\text { Overall } \\
\text { district } \\
N=259 \\
n(\%)\end{array}$ \\
\hline Viral infection skin e.g shingles & $\begin{array}{c}0 \\
(0)\end{array}$ & $\begin{array}{c}1 \\
(1.9)\end{array}$ & $\begin{array}{c}0 \\
(0)\end{array}$ & $\begin{array}{c}1 \\
(2.1 \%)\end{array}$ & $\begin{array}{c}1 \\
(1.8)\end{array}$ & $\begin{array}{c}0 \\
(0)\end{array}$ & $\begin{array}{c}0 \\
(0)\end{array}$ & $\begin{array}{c}3 \\
(1.2)\end{array}$ \\
\hline Mycoses e.g tinea pedis & $\begin{array}{c}1 \\
(1.9)\end{array}$ & $\begin{array}{c}0 \\
(0)\end{array}$ & $\begin{array}{c}0 \\
(0)\end{array}$ & $\begin{array}{c}1 \\
(2.1)\end{array}$ & $\begin{array}{c}0 \\
(0)\end{array}$ & $\begin{array}{c}0 \\
(0)\end{array}$ & $\begin{array}{c}0 \\
(0)\end{array}$ & $\begin{array}{c}2 \\
(0.8)\end{array}$ \\
\hline
\end{tabular}

\section{Scabies} Disorder of eye e.g style, periorbital cellulitis,
eyelid abscess

Disorder of ear e.g otitis externa

0

(0) (0)

0

(0)

$(3.8 \%) \quad(2.3)$

0

(0)

(2.1)

0

0
$(0)$

1

1
$(8.3)$

0
$(0)$

2

$\begin{array}{cc}1 & 0 \\ (1.9) & (0)\end{array}$

\begin{tabular}{l}
\hline Disorder of respiratory system \\
\hline Disorder of oral cavity e.g gingivitis
\end{tabular}

0
$(0)$

0

0
$(0)$

$1 \quad 1$

(2.1) (1.8)

0

(0)

4

(16.7)

$(0.8)$

$0 \quad 0$

(0)

(0)

$\begin{array}{cc}0 & 1 \\ (0) & (2.1)\end{array}$

1
$(1.8)$

0

(0)

(0)

(4.2)

0

(0)

(0)

(0)

2

(8.3)

(3.6)

(0)

Disease of digestive system e.g perianal abscess

\section{Disorder of breast e.g mastitis}

(0)

(0)

0

(0) $\quad(1.80$

0
$(0)$

0

$(0)$

1

(0)

$\begin{array}{cc}0 & 0 \\ 0 & (0) \\ 0 & 0\end{array}$

Disorder of Bartholin gland e.g Bartholin's cyst,

bartholin abscess

(0)

0
$(0)$

(0)

Symptom - localised lymphadenopathy

Diabetic foot ulcer

0
$(0)$

(0)

(0)

0
$(0)$

1

(2.1)

(1.8)

0
$(0)$

0
$(0)$

1
$(1.8)$

0
$(0)$

$\begin{array}{cccccc}(0) & (2.1) & (1.8) & (0) & (0) & (0.8) \\ 0 & 0 & 0 & 1 & 0 & 1 \\ (0) & (0) & (0) & (8.3) & (0) & (0.4) \\ 0 & 0 & 2 & 0 & 1 & 3\end{array}$

$\begin{array}{cc}0 & 0 \\ (0) & (0)\end{array}$

\begin{tabular}{l} 
Injury of unspecified body region e.g laceration \\
wound \\
\hline Burn and corrosion
\end{tabular}

Allergic reaction
$\begin{aligned} & \text { Post procedural complication e.g infected } \\ & \text { wound post excision }\end{aligned}$

\begin{tabular}{l} 
wound post excision \\
\hline Bitten by dog
\end{tabular}

$\begin{array}{ccc}2 & 1 & 0 \\ (3.8) & (2.3) & (0)\end{array}$

0
$(0)$

0
$(0)$

$\begin{array}{ccc}1 & 0 & 0 \\ (1.9) & (0) & (0)\end{array}$

$\begin{array}{cc}0 & 3 \\ (0) & (6.4)\end{array}$

3
$(6.4)$

$(1.6)$

(0)

$\begin{array}{ccc}0 & 0 \\ 0 & 0 & 0 \\ (0) & (0) & (0)\end{array}$

$\begin{array}{ccc}1 & 0 & 0 \\ (1.9) & (0) & (0)\end{array}$

$\begin{array}{cc}0 & 0 \\ (0) & (0)\end{array}$

0
$(0)$

$\begin{array}{cc}0 & 0 \\ (0) & (0)\end{array}$

No diagnosis

$\begin{array}{cc}0 & 0 \\ (0) & (0) \\ 12 & 4 \\ (23.1) & (9.3)\end{array}$

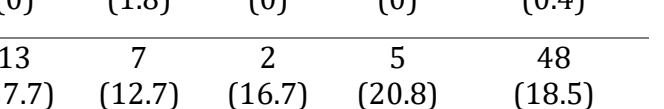

$\begin{array}{cc}5 & (0) \\ (19.2) & (27.7)\end{array}$

During a cross-tabulation of those with inaccurate diagnosis, $100 \%(\mathrm{n}=48)$ prescriptions were the ones without diagnosis
Abbreviations: KKBJ; Bestari Jaya health clinic, KKBC; Bukit Cherakah health clinic, KKI; Ijok health clinic, KKJ; Jeram health clinic, KKKS; Kuala Selangor health clinic, KKSTK; Sungai Tengi Kanan health clinic, KKTK; Tanjong Karang health clinic 


\section{DISCUSSION}

This is a preliminary study looking at appropriate Cloxacillin use in Kuala Selangor district. Findings showed that appropriate Cloxacillin use was low compared to national standards $(>80 \%)^{8}$. The overuse and misuse of antibiotics have contributed to the increase bacterial resistance to the antibiotic ${ }^{2}$. A majority of patients receiving antibiotics in this district were predominantly male, consistent with another study done in South India ${ }^{9}$. Adherence and appropriateness of Cloxacillin prescriptions was low compared to the National Antibiotic guideline, similar with a study conducted in Kedah, Malaysia $^{2}, 6$. Similar with the study conducted in Kedah, majority of Cloxacillin was prescribed for infection of the skin and subcutaneous tissue ${ }^{6}$.

Some recommendations include revising swab culture and sensitivity requirement in AMS protocol and conducting several short antibiotic courses among prescribers $2,10,11$. Periodic measurement on appropriate utilization of Cloxacillin is necessary for all primary health care facilities ${ }^{8}$.

Limitations of this study included missing data and clinically relevant as some prescriptions and records had no diagnosis stated, missing (failed to retrieve manually) and had double entry of the same patient. This study provided crucial platform to strengthen our measures on Cloxacillin use to prevent rapid antimicrobial resistance and jurisdiction of healthcare cost.

Concentrating into prescriber's factors (background, knowledge, attitude and perception towards antibiotic prescription) and unnecessary Cloxacillin prescriptions for other disease than infection of skin and subcutaneous tissue should be emphasized in future study ${ }^{8}$.

\section{CONCLUSION}

Adherence and appropriateness of Cloxacillin prescriptions were low at public health care clinics in Kuala Selangor District, hence there is a need to take measures to improve appropriate Cloxacillin usage and prescription to ensure adherence to the National Antibiotic Guideline (NAG) and Antimicrobial Stewardship (AMS) protocol in order to prevent rapid antimicrobial resistance.

\section{Acknowledgement}

We would like to thank Madam Jasrinjeet Kaur (pharmacist) for her technical contribution in this study.

\section{Conflict of Interest}

Nil

\section{References}

1. Cordoba G, Sorensen TM, Holm A, et al. Exploring the feasibility and synergistic value of the One Health approach in clinical research: Protocol for a prospective observational study of diagnostic pathways in human and canine patients with suspected urinary tract infection. Pilot Feasibility Stud. 2015; 1:38. https://doi.org/10.1186/s40814-015-0036-9

2. Ministry of Health Malaysia. National Antibiotic Guideline Third Edition 2019.

3. Ministry of Health Malaysia. Medicines Formulary 2015.

4. Ministry of Health Malaysia. Malaysia Health System Research (MHSR) Contextual Analysis. 2016.

5. Shamsuddin S, Akkawi ME, Zaidi ST, et al. Antimicrobial drug use in primary healthcare clinics: a retrospective evaluation. Int J Infect Dis. 2016; 52:16-22. https://doi.org/10.1016/j.ijid.2016.09.013

6. Tan GH, Low QW, Lim HC, et al. Inappropriate antibiotic utilization: Outpatient prescription review of a regional secondary hospital in Kedah, Malaysia. Journal of Pharmacy Practice and Community Medicine. 2017; 3(4):215-219. https://doi.org/10.5530/jppcm.2017.4.62

7. Ab Rahman N, Teng CL, Sivasampu S. Antibiotic prescribing in public and private practice: A cross-sectional study in primary care clinics in Malaysia. BMC Infect Dis. 2016; 16:208. https://doi.org/10.1186/s12879-016-1530-2

8. Ministry of Health Malaysia. Protocol on Antimicrobial Stewardship Program in Healthcare Facilities. 2014.

9. Meena DK, Jayanthi M. Monitoring antibiotic use in public health care facilities of South Indian Union Territory: A step to promote rational use of antibiotics. Cureus. 2021; 13(10):e18431. https://doi.org/10.7759/cureus.18431

10. Che Roos NA, Bakar MA, Haque M. Knowledge, attitude and practice among Malaysian medical students, doctors, other health professionals and common people regarding antibiotic use, prescribing and resistance: A systematic review. Adv Hum Biol. 2019; 9:179-93. https://doi.org/10.4103/AIHB.AIHB_42_19

11. Lim AH, Thian SY, Hor YY, et al., Antibiotic prescribing pattern in primary care practice in Federal Territory Kuala Lumpur and Putrajaya, International Journal of Infectious Diseases. 2020; 101(S1) (2021) 8-119. https://doi.org/10.1016/j.ijid.2020.09.264 